This Journal is available in Telkom University online Journals

Jurnal Manajemen Indonesia

Journal homepage: journals.telkomuniversity.ac.id/ijm

\title{
The Relationship Between Financial Literation Towards Users Of Loan Transacted Applications In The Millennial Generation
}

\author{
Retno Setyorini ${ }^{1}$, Candra Wijayangka ${ }^{2}$, Fikri Haikal ${ }^{3}$ and Nugraha ${ }^{4}$ \\ 1,2,4 Management Study Program, Education, Indonesia University of Education, Bandung, Indonesia \\ 1,2,3 Business Administration Study Program, Telkom University, Bandung,Indonesia
}

\begin{abstract}
This study aimed to find a relationship between financial literacy and the use of loans transacted for the millennial generation - quantitative approach research method. The population in this study is the millennial generation in Bandung who have made loans transacted. The sample used was 270 people with a non-probability sampling technique with the criteria of users of online loan fintech products. The analysis technique used is a simple correlation and regression test. The results obtained show a significant influence between financial literacy variables on loans transacted with a t-value of 6,947. While the results of the correlation test state that the contribution of financial literacy to loans transacted has a contribution of 0.567, meaning that there is a fairly close relationship in terms of positive linear correlation value $(r=1)$, which means that every increase in financial literacy can increase the level of loans transacted
\end{abstract}

Keywords-; Fintech; Financial Literacy; Loans transacted Applications;Millenial

\begin{abstract}
Abstrak
Tujuan penelitian ini adalah untuk mencari hubungan antara literasi keuangan terhadap pemanfaatan pinjaman online pada generasi milenial. Metode penelitian pendekatan kuantitatif. Populasi dalam penelitian ini adalah generasi milenial di Kota Bandung yang pernah melakukan transaksi pinjaman online. Sample yang digunakan sebanyak 270 orang dengan teknik pengambilan sampel non-probability sampling dengan kriteria pengguna produk fintech pinjaman online. Teknik analisi yang digunakan adalah uji korelasi dan regresi sederhana. Hasil penelitian yang didapat adalah terdapat pengaruh yang signifikan antara variabel literasi keuangan terhadap pinjaman online dengan t-value 6.947. Sedangkan hasil uji korelasi menyebutkan bahwa kontribusi literasi keuangan terhadap pinjaman online memiliki kontribusi 0.567 , artinya terdapat hubungan yang cukup erat ditinjau juga dengan nilai korelasi linier positif ( $\mathrm{r}=1$ )yang artinya setiap terjadi kenaikan literasi keuangan dapat menaikan tingkat pinjaman online.
\end{abstract}

Kata kunci- Aplikasi Pinjaman Online; Fintech; Literasi Keuangan; Milineal

\section{INTRODUCTION}

The development of the financial sector is recognized as a determinant of a country's economic growth (Cole, Sampson, \& Zia, 2011) As technology advances rapidly, financial technology (fintech) is introduced to the public as a technology-based financial service that can help people make financial transactions anytime and anywhere (Istiqamah, 2019)

Fintech, which is present in the community, provides technology-based financial services with a new business model that can indirectly impact monetary stabilization, financial system stabilization, efficiency, smoothness, security, and reliability in the payment system (Supriyanto \& Ismawati, 2019). Otoritas Jasa Keuangan (OJK), on August 14, 2020, recorded the number of registered peers to peer lending fintech operators as many as 157 companies that have been registered and have a license. Meanwhile, peer to peer lending fintech loans continued 
to increase from 2016 to June 2020, and the total online loan financing reached Rp. 113.46 trillion or grew by 153.23\% compared to June 2019 (Miftahudin, 2020).

Service innovation provided in fintech products provides convenience and ease of transactions, especially for the Millennial generation, which should make fintech a catalyst for healthy financial behavior (Ulinnuha, 2017). Healthy financial behavior, of course, must start from an early age; currently, consumptive behavior is so dominant among adolescents, this is because psychologically there is a formation of identity which is influenced by outside influences (Sumartono, 2008)

With the ease of conducting financial transactions, making decisions about the use of money becomes a special consideration. Making wrong decisions can result in bad and ineffective management of an economy potentially vulnerable to financial crises (Ningtyas, 2019). For this reason, financial literacy greatly affects every decision made. According to research conducted by the OJK, millennials aged 18-25 years only have a financial literacy rate of $32.1 \%$, while those aged 25-35 years have a financial literacy rate of 33.5\% (Siringoringo, 2020)

According to Manurung (2009), financial literacy can be a skill and knowledge tool that allows a person to make effective financial resources decisions. Meanwhile, research Huston (2010) suggests that financial literacy has a multi-dimensional character, which means that it does reflect not only knowledge (financial knowledge) but also skills (financial skills), attitudes (financial behavior), and actual behavior (financial attitude).

Based on a survey conducted by the Global Financial Literacy Survey in 2015, the countries with a high financial literacy level were Denmark and Norway, with $71 \%$. Meanwhile, Indonesia, based on the survey, its financial literacy rate was still $32 \%$, still lagging behind neighboring Malaysia with a financial literacy rate of $36 \%$. Percent. This is still quite low compared to the level of financial literacy globally ( (Klapper, Lusardi, \& Oudheusden, 2015)

The use of this loan service will be beneficial if the customer or user of this service has a good literacy level in making decisions to overcome financial problems. Still, it will be a problem in the future if there is a case of default. Based on this explanation, this study will examine how financial literacy relates to the use of online loan application users for the millennial generation in Bandung, West Java, Indonesia.

\section{HYPOTHESIS DEVELOPMENT}

\section{A. Financial Technology}

Fintech has multi-functions, which have various kinds of electronic money services, virtual accounts, aggregators, lending, crowdfunding, and other online financial transactions (Istiqamah, 2019). One of them is an online loan that uses a peer-to-peer lending fintech application, which is currently used as an effective and efficient financing solution that can make it easier for people to make loans without being limited by space and time (Supriyanto \& Ismawati, 2019).

Loans transacted s are becoming a new business model using technology; this platform can meet loan needs where the requirements offered are easier than loans managed by banks. In terms of operational costs, this online loan platform has lower costs and higher efficiency than traditional bank loans (Hsueh, 2017).

According to Omarini (2018), Online lending has three dimensions: Lender, Borrower, and Platform. In OJK regulation number 77 / PJOK.01 / 2016 concerning information technology-based lending and borrowing services, the three dimensions are regulated in articles, including: (1) Lenders are in article one paragraph eight. Stating that "a lender is a person, legal entity, and/or business entity that has receivables due to an information technologybased lending and borrowing service agreement." (2) The borrower in article one, paragraph seven. Declare that, "The Borrower is a person and/or legal entity that has a debt due to an information technology-based lending and borrowing service agreement"; and (3) Platform in article one paragraph three. Stating that "information technology-based lending and borrowing services are the provision of financial service.

\section{B. Financial Literacy}

The Organization for Economic Co-operation and Development (OECD) in 2017 argued financial literacy as knowledge and understanding of financial concepts and risks, along with skills, motivation, and confidence to apply this knowledge and understanding to make effective financial decisions, improve the financial well-being of individuals and communities, and participate in the economic field. Huston (2010) argues that financial literacy 
has two dimensions: (1) understanding, which represents knowledge of personal finance in financial education; (2) use, which is related to knowledge in terms of managing personal finances. Individuals are said to have financial knowledge if they already have the ability and confidence to apply it when making decisions (Potrich, Viera, \& Mendes-Da-Silva, 2016).

In research Potrich, Viera, \& Mendes-Da-Silva (2016) that financial literacy is focused on divided into three dimensions, namely:

a) Financial Knowledge, understanding, knowledge, and an individual basic understanding of finance, as a means of making correct financial decisions.

b) Financial Behavior, how individual behavior in financial management, such as consistency in saving, recording all expenses, and setting financial targets.

c) Financial Attitude, an individual's attitude stating that any particular financial condition results from the individual's thoughts, opinions, and assessment

The results of research conducted in the United States, the average level of financial knowledge of adult women is lower than that of men. A married person is considered to have more motivation to increase wealth, for example, by investing, pension funds and other long-term plans. People who have more wealth are also more likely to be interested in financial products such as insurance, pensions, capital market products such as stocks (Lusardi \& Mitchell, 2011).

Other studies suggest that a lack of financial literacy is one of the factors that can cause errors in borrowing decisions; it can encourage someone to borrow excessively (Sevim, Temizel, \& Sayilir, 2012). This statement is supported by research conducted by Artavanis \& Karra (2020). that loan service users who have a good literacy level tend not to have financial problems in the future, and there are no cases of default. This is because service users who have good literacy levels can properly calculate the costs and benefits obtained. Likewise, service users who have lower literacy levels are more likely to face financial problems in the future due to a lack of insight and financial planning ability.

Based on the description above in this conceptual framework, the hypothesis and research framework are as follows:

H0: there is no relationship between financial literacy and loans transacted

H1: There is a relationship between financial literacy and loans transacted

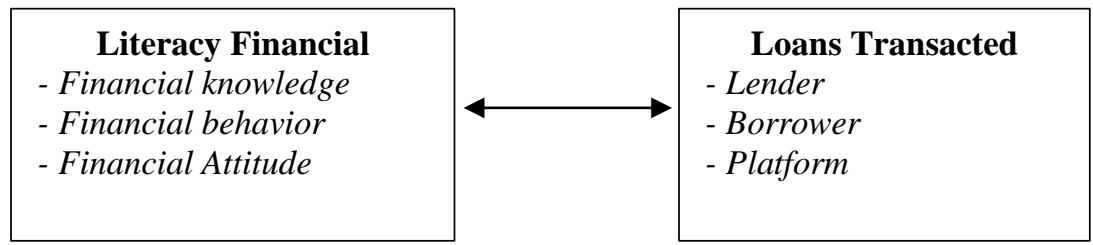

Figure. 1 Research Framework (Potrich, Viera, \& Mendes-Da-Silva, 2016; Omarini, 2018)

\section{RESEARCH METHODS}

\section{A. Research Design}

This research is research with a qualitative approach. This study's population is the millennial generation in the city of Bandung, who have made an unknown number of online loan transactions. The sample used was 270 people with a non-probability sampling technique with the criteria of users of online loan fintech products.

This model aims to measure the correlation between financial literacy and loans transacted for the millennial generation of online loan service users in Bandung, West Java. In this study, financial literacy and online loan variables consisted of 3 dimensions of 9 measurement items, so the total measurement items were 18 items.

Distribution of questionnaires using the Google application; this is because research has limited time and funds. The questionnaire adopted a Likert scale with 5 points, namely "Strongly Agree," "Agree," "Moderate," 
"Disagree," and "Strongly Disagree." This questionnaire has been compiled through validity and reliability. The data collected was then analyzed using the correlation analysis method between the two variables.

\section{B. Sample Characteristic}

The research is focused on the millennial generation who have made loans transacted until November 2020. The sample of respondents was compiled based on demographic factors as follows:

Table 1. Sample Characteristic

\begin{tabular}{lccclr}
\hline & Gender & & Age & \multicolumn{2}{c}{ Ocupation } \\
\hline Male & $54 \%$ & $<20$ & $11 \%$ & Student & $68 \%$ \\
Female & $46 \%$ & $21-25$ & $70 \%$ & Employees & $16 \%$ \\
& & $>25$ & $19 \%$ & Entrepeneur & $7 \%$ \\
& & & & Other & $9 \%$ \\
\hline
\end{tabular}

Based on the results of observations made in table 1.Distribution of questionnaires based on the criteria of research conducted by OJK, namely, the millennial generation aged 18-25 years only has a financial literacy level of $32.1 \%$ while those aged 25-35 years have a financial literacy level of 33, 5\% (Siringoringo, 2020) this is intended to find out how much correlation between financial literacy and loans transacted.

\section{Methods}

The distribution of questionnaires was carried out by 18 items for indicators of each dimension in Financial Literacy Potrich, Viera, \& Mendes-Da-Silva (2016) and loans transacted Omarini (2018). How to assess the answers to each statement of the respondent's attitude using a Likert scale. Instrument testing is done by testing the validity and reliability, converted to ordinal data into interval data using the Method of Successive Interval (MSI). Then performed the Data Normality Test and measurement of the correlation coefficient between the two variables.

Measurement of the hypothesis testing criteria as according to Priyanto (2017) is as follows: if t-table $>\mathrm{t}-$ value or $\mathrm{t}$-value $<\mathrm{t}$ table and a significance value $>0.05$, then $\mathrm{H} 0$ is accepted, and $\mathrm{H} 1$ is rejected, $\mathrm{t}$-value $<\mathrm{t}$-table or $\mathrm{t}$-value $>\mathrm{t}$ table and a significance value $<0.05$, then $\mathrm{H} 0$ is rejected, and $\mathrm{H} 1$ is accepted.

\section{RESUlt AND Discussion}

\section{A. Result}

In Table 2. The test results on 18 question items from the two variables, using the person product-moment correlation formula where the $r$-value $>$ r-table are obtained, where the r-table value is 0.361 with a significance level of $<0.05$, then the 18 statements are declared valid.

Table 2. Validity Test Result

\begin{tabular}{cccc}
\hline \multicolumn{2}{c}{ Literacy Financial } & \multicolumn{2}{c}{ Loans Transacted } \\
\hline No. & r-value & No. & r-value \\
\hline 1. & .717 & 10. & .662 \\
2. & .575 & 11. & .581 \\
3. & .842 & 12. & .874 \\
4. & .785 & 13. & .761 \\
5. & .527 & 14. & .803 \\
6. & .635 & 15. & .799 \\
7. & .680 & 16. & .535 \\
8. & .651 & 17. & .569 \\
9. & .833 & 18. & .749 \\
\hline
\end{tabular}


While the reliability test in this study used the Cronbach Alpha $(\alpha)$ statistical calculation technique, the test results will determine the indicators of the statements used in this study are reliable or not. The results of reliability testing, it can be seen that the variable financial literacy and loans transacted are reliable because the results of the reliability test using the SPSS application have a value greater than the Alpha Cronbach value with a value of 0.7 or $70 \%$ with a significance level of 0.05 (Table 3 ).

Table 3. Reliability Test Result

\begin{tabular}{cccc}
\hline Variable & Cronbach Alpha & Criteria & Description \\
\hline Loans Transacted & .851 & .70 & Reliable \\
Literacy Financial & .862 & .70 & Reliable \\
\hline
\end{tabular}

The data test is continued by conducting a normality test, which functions to test whether the residual value generated from the regression is normally distributed or not. A good regression model has a residual value that is normally distributed because normally distributed data can be considered representative of the population. Data normalization is also a basic requirement that must be met in the parametric analysis. The most frequently used data normality test for SPSS applications is the Kolmogorov-Smirnov method (Priyanto, 2017). The results in table 4. indicate that the significant value in this study is 0.052 , which is greater than the significance level of 0.05 , so it can be concluded that the data in this study are normally distributed.

Table 4. One-Sample Kolmogorov-Smirnov Test

\begin{tabular}{llr}
\hline $\mathrm{N}$ & & 270 \\
\hline Normal Parameters ${ }^{\mathrm{a}, \mathrm{b}}$ & Mean & .000000 \\
& Standard Deviation & .35111222 \\
Most Extreme Differences & Absolute & .054 \\
& Positive & .03 \\
& Negative & -.054 \\
Test Statistic & & .054 \\
Asymp. Sig. (2-tailed) & & $.052^{\mathrm{c}}$ \\
\hline
\end{tabular}

To determine the correlation between two variables, namely financial literacy and loans transacted, the correlation coefficient test was conducted to determine the strength of the relationship between two or more variables or determine the direction of the two variables. With the correlation value $(r)=(-1 \leq 0 \leq 1)$ (Siregar, 2017). The strength of the relationship, the correlation coefficient value is between -1 and 1 , while the direction is expressed in a positive or negative form with the following conditions:

$r=-1$ means a perfect negative correlation, there is an opposite relationship between variables.

$\mathrm{r}=1$ means perfect positive correlation, meaning that there is a unidirectional relationship between variables

Table 5. Correlations Test Result

\begin{tabular}{llrr}
\hline & & Literacy Financial & Loans Transacted \\
\hline Literacy Financial & Pearson Correlation & 1 & $.567^{* *}$ \\
& Sig. (2-tailed) & & .000 \\
& $\mathrm{~N}$ & 270 & 270 \\
\hline Loans Transacted & Pearson Correlation & $.567^{* *}$ & 1 \\
& Sig. (2-tailed) & .000 & 270 \\
& $\mathrm{~N}$ & 270 & \\
\hline
\end{tabular}

The correlation test results found in table 5 show that the correlation coefficient between financial literacy and loans transacted is 0.567 . If viewed from the level of correlation and the strength of the relationship (Siregar, 2017) the two variables have a sufficient relationship, and $r=1$, then every increase in financial literacy can increase the rate of loans transacted. 
Table 6. Hypothesis Test Results

\begin{tabular}{|c|c|c|c|c|c|}
\hline \multirow{2}{*}{ Model } & \multicolumn{2}{|c|}{ Unstandardized Coefficients } & \multirow{2}{*}{$\begin{array}{c}\text { Standardized Coefficients } \\
\text { Beta }\end{array}$} & \multirow{2}{*}{$\mathrm{t}$} & \multirow{2}{*}{ Sig. } \\
\hline & $\mathrm{B}$ & Std. Error & & & \\
\hline $1 \quad$ (Constant) & 2.310 & .135 & & 17.088 & .000 \\
\hline Financial Literacy & .301 & .043 & .391 & 6.947 & .000 \\
\hline
\end{tabular}

Based on the results of hypothesis testing in table 6 . The results of this study indicate that financial literacy has a significant effect on loans transacted; this statement is evidenced by the results of hypothesis testing showing the value of t-value $>\mathrm{t}$ table $(6,947>1,968)$ and with a Sig value of $0.000<0.05 . \mathrm{H}_{0}$ is rejected, and $\mathrm{H}_{1}$ is accepted, which means that there is an influence between Financial Literacy on Loans transacted.

\section{B. Discussion}

According to research conducted by (Yakoboski, Hasler, \& Lusardi, 2018), financial technology does not always make someone financially literate. This study also found that individuals who have good financial literacy tend to do good personal financial management. (Lusardi \& Mitchell, 2011) explained that there is a significant relationship between financial literacy and age; along with increasing age, there is an increase in financial literacy from time to time. The relationship between financial literacy and online lending is strengthened by research (Sihombing, Suryanto, Mahameru, Setiawan, \& Marsella, 2019)suggesting that students with unstable economic backgrounds will undoubtedly be happy with loans transacted, only using identity cards and student identification card as collateral. Hence, there is no need to attach a salary slip. However, these factors can have a consumptive impact on students.

In line with research conducted by (Halim \& Astuti) financial knowledge can make individuals have understanding, analytical skills, and managing finances to enforce these finances to avoid financial problems properly. This statement is supported by research conducted by (Lestari, 2015) A person who has a high level of financial literacy will be able to choose and utilize financial products and services that suit their needs, and get an understanding of the benefits of the risks of financial products and services, and vice versa.

\section{CONCLUSION}

Based on the results of the study, it shows that financial literacy has a significant effect on loans transacted, meaning that financial literacy is a measure of the extent to which people can understand the main concepts of finance, the ability of individuals to manage personal finances and make decisions about personal financial factors. The correlation test results support that financial literacy on loans transacted has a sufficient relationship with a positive linear correlation. It can be concluded that every increase in financial literacy can increase the level of loans transacted. This statement is supported by research conducted by Lestari (2015). Declare that someone who has a high level of financial literacy will be able to choose and utilize financial products and services according to their needs and get an understanding of the benefits of the risks of financial products and services, and vice versa.

The measurement of financial literacy can predict individual behavior in managing and making policies in personal finances. Apart from internal conditions, of course, making decisions is influenced by external aspects. Further research can carry out financial literacy in a deeper view of demographic factors by adding daily financial activities by adding external factors that affect the individual's financial behavior.

\section{REFERENCES}

Cole, S., Sampson, T., \& Zia, B. (2011). Prices or Knowledge? What Drives Demand for Financial Services in Emerging Markets? The Journal of Finance, 1933-1967.

Istiqamah, I. (2019). ANALISIS PINJAMAN ONLINE OLEH FINTECH DALAM KAJIAN HUKUM PERDATA. Jurisprudentie, 291-306.

Supriyanto, E., \& Ismawati, N. (2019). SISTEM INFORMASI FINTECH PINJAMAN ONLINE BERBASIS WEB. Jurnal Sistem Informas, Teknologi dan Komputer, 100-107. 
Rahma, T. F. (2018). PERSEPSI MASYARAKAT KOTA MEDAN TERHADAP PENGGUNAAN FINANCIAL TECHNOLOGY (FINTECH). At-Tawassuh, 642-661.

Miftahudin, H. (2020, September 08). https://www.medcom.id/ekonomi/keuangan/nbwjVBEN-afpiperkembangan-fintech-ri-paling-pesat-di-asia-tenggara. Retrieved Desember 2020, from https://www.medcom.id/ekonomi/keuangan/nbwjVBEN-afpi-perkembangan-fintech-ri-paling-pesat-diasia-tenggara

Ulinnuha, I. H. (2017, February 14). "Fintech" dan Perilaku Keuangan Generasi Milenial Artikel ini telah tayang di Kompas.com dengan judul "'Fintech" dan Perilaku Keuangan Generasi Milenial", Klik untuk baca: https://money.kompas.com/read/2017/02/14/090100326/.fintech.dan.perilaku.keuangan. Retrieved December 2020, from https://money.kompas.com: https://money.kompas.com/read/2017/02/14/090100326/.fintech.dan.perilaku.keuangan.generasi.mileni al?page $=$ all

Sumartono, S. (2008). Terperangkap dalam Iklan: Meneropong imbas pesan Iklan Televisi. Bandung: Alfabeta.

Ningtyas, M. N. (2019). Literasi Keuangan pada Generasi Milenial. Jurnal Ilmiah Bisnis dan Ekonomi Asia, 2027.

Siringoringo, L. (2020, December 2). Kalangan milenial masih belum melek soal literasi keuangan. Retrieved December 2020, from https://keuangan.kontan.co.id/news/kalangan-milenial-masih-belum-melek-soalliterasi-keuangan

Manurung, J. (2009). Ekonomi Keuangan dan Kebijakan Moneter. Jakarta: Salemba Empat.

Huston, S. (2010). Measuring Financial Literacy. The Journal of Consumer Affairs, 296-316.

Klapper, L., Lusardi, A., \& Oudheusden, P. (2015, December 20). Financial Literacy Around the World: Insight From The Standard \& Poor's Ratings Services Global Financial Literacy Survey. Retrieved from https://gflec.org: https://gflec.org/wp-content/uploads/2015/11/Finlit_paper_16_F2_singles.pdf

Hsueh, S. (2017). Effective Matching for P2P Lending . ICIBE (pp. 30-33). Mining Strong Association Rules.

Potrich, A. G., Viera, K., \& Mendes-Da-Silva, W. (2016). Development of a financial literacy model for university students. Management Research Review, 356-376.

Anna Eugenia Omarini. (2018). Peer-to-Peer Lending: Business Model Analysis and the Platform Dilemma. International Journal of Finance, Economics and Trade (IJFET), 31-41.

Lusardi, A., \& Mitchell, O. (2011). Financial literacy around the world:an overview. Journal of Pension Economics \& Finance, 497-508.

Sevim, N., Temizel, F., \& Sayilir, O. (2012). The effects of financial literacy on the borrowing behaviour of Turkish financial consumers. International Journal of Consumer Studies, 573-579.

Artavanis, N., \& Karra, S. (2020). Financial literacy and student debt . The European Journal of Finance, 382401.

Wulandari, M., \& Yuliati, A. L. (2019). Pengaruh shopping Lifestyle, Discount dan Fashion Involvement Terhadap Impulse Buying Pengunjung Transmart Carrefour Buah Batu Bandung. Jurnal Ilmiah Manajemen Ekonomi \& Akuntansi, 1-14.

Sangadji, E. M., \& Sopiah. (2018). Perilaku Konsumen, Pendekatan Praktis: Disertai Himpunan Jurnal Penelitian. Yogyakarta: Andi Offset.

Engel, J. F., \& Blackwell, R. D. (2016). Perilaku Konsumen. Tangerang: Binarupa Aksara.

Priyanto, P. (2017). Panduan Praktis Olah Data Menggunakan SPSS. Yogyakarta: Andi Offset.

Siregar, S. (2017). Metode Penelitian Kuantitatif Dilengkapi Dengan Perbandingan Perhitungan Manual \& SPSS. Jakarta: Kencana.

Yakoboski, P., Hasler, A., \& Lusardi, A. (2018). Millennial Financial Literacy and Fin-tech Use: Who Knows What in the Digital Era. New York: TIAA Institute.

Sihombing, N. M., Suryanto, N., Mahameru, M., Setiawan, M., \& Marsella, E. (2019). Dampak Penggunaan Pinjaman Online terhadap Gaya Hidup Konsumtif Mahasiswa Yogyakarta. SINTAK (pp. 500-507). UNISBANK. 
Lestari, S. (2015). Literasi Keuangan serta Penggunaan Produk dan Jasa Lembaga Keuangan. Jurnal Fokus Bisnis, $14-25$.

Halim, Y., \& Astuti. (n.d.). Financial Stressors, Financial Behavior, Risk Tolerance, Financial Solvency, Financial Knowledge dan Kepuasan Fianansial. 3(1), 29-23. 